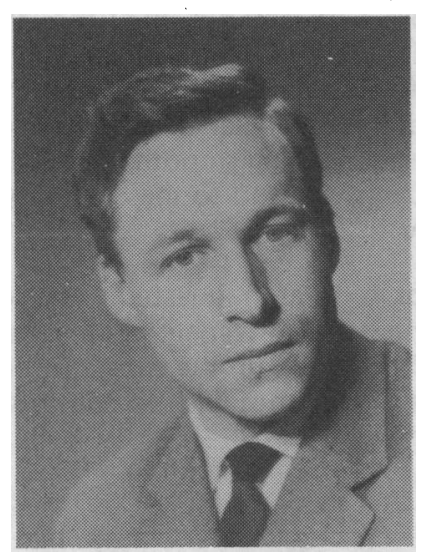

H. Meusel

\section{DEVELOPING PHYSICAL FITNESS FOR THE ELDERLY THROUGH SPORT AND EXERCISE*}

\author{
H. MEUSEL (translation: StD Walter MEUSEL)
}

\footnotetext{
* Lecture on the 11th Annual Fitness After Fifty Workshop Conference at the Center for the Study of Ageing, Albany, NY (USA), 30th September-2nd October.

Address for correspondence:

Prof. Dr. Heinz Meusel,

In practice sports and exercise for the elderly are mostly a continuation of the kind of training that they undertook as youngsters and competitors, though with reduced work loads. In most cases training programmes for the elderly are confined to one sport only.
}

Sportwissenschaftliches Institut, Kugelberg 62, D 63 Gießen

We try to explain why it is necessary to consider as that have grown out of a "trunk" already weakened by disease and age, but basically this image contains a lot of truth. In order to convey the full meaning of physical fitness for personality development we shall have to make a few preliminary remarks.

Today there can hardly be any doubt that one has to lead an active life in order to maintain physical fitness in old age (Lehr, 1974 and 1978). In the field of motor performance different concepts are offered. They lay stress either on improving flexibility (e.g. in gymnastics for senior citizens), on endurance (e.g. in sports medicine) or, in addition to these, on further factors of motor mobility (Hollmann et al, 1978). 
many abilities and skills as possible when planning training programmes to maintain and improve motor performance in old age (Meusel, 1982).

\section{Physical fitness and personality development}

The general physical structure and condition of a person's body is designed for movement. We can take this from the phylogenesis and ontogenesis of the human being. The structure of our organic systems can only be understood fully if we also consider their original functions in the human species' struggle for life. Even our cerebrum has developed its present performance mainly because our motor performance has been challenged by a great variety of tasks. Our cerebrum has not been developed primarily by processes of thinking but by being compelled to guide and control a repertory of movements that are capable of development in mastering living conditions that constantly keep changing.

Before discussing the importance of physical activity and sports for the elderly we first have to examine this specific interdependence between motor activities and personality. Motor activities are of the utmost importance for the development of the individual throughout his lifetime. The individual forms his idea of the world around him and his conception of society by means of psycho-motor actions. A small child - as one can easily observe - "grasps" his environment by "grasping" it with his hands. The individual also communicates with other people and with his environment through motor activities (facial expressions, gestures, language). In other words, motor activities play the part of an intermediary in the exchange of information between the environment and the individual, the individual and his environment.

From his early infancy the individual must be stimulated by diverse physical activities to develop his physical and mental condition normally. Through lack of exercise and want of affection his physical and mental development is restricted and delayed (deprivation syndrome caused by hospitalisation).

The importance of physical activities for promoting the performance of our organic systems and for improving our general well-being can easily be substantiated. We need only observe people who have been confined to bed for several weeks. The muscles are beginning to atrophy, the performance of the circulatory system is reduced, the sense of balance and other coordinative skills are impaired. We also know that many phenomena which have so far been thought to be due to natural consequences of the ageing process can now be traced back to conditions, some essential factors of which have been caused by lack of physical activity and exercise and not primarily by the process of growing old. If people take adequate exercise they can maintain their good physical performance even after having reached old age (Jokl, 1970; Schneiter, 1973). This has been confirmed by the performance of many old people in almost all organic systems.

In principle we can say that - with the exception of certain cases of disease or infirmity - all our organic systems can be trained right into old age and that their performance mainly depends on how often and how much we take adequate exercise.

Our organism is a dynamic, self-regulating system the functioning of which depends on the efficiency of numerous subsystems, which on their part depend on each other. Among those subsystems there are the central nervous system, the autonomic nervous system, the musculo-skeletal system, the cardiovascular system, metabolism, and the immune system.

What matters is to influence the individual subsystems in such a way as to regain or maintain physical fitness and well-being. This can for instance be done by taking medicines and by doping. The influence that anabolic drugs have on strength and that relaxing drugs have on our general well-being is well known. However, before taking medicines and dopes possible side-effects and damage have to be taken into consideration. Apart from taking medicines one can also influence the individual subsystems or the organism as a whole through sports. As everybody knows, different sports influence and develop different subsystems of our organism. The longdistance runner, who wants to improve endurance, mainly activates the capacity of $h$ is cardiovascular system and corresponding psychic qualities of volition, such as will-power. The body-builder increases the crosssectional area of his muscles, he strengthens his muscles, tendons and ligaments. People who practice shooting improve the precision of their motor performance and their ability to concentrate. Players in team games improve physical agility, reaction and other aspects of co-ordinative skills.

Which way of life can therefore be considered to be the most suitable for developing and maintaining all our organic systems and dispositions? It is a way of life, based on a wide range of sports, that promotes our physical fitness and keeps it on a comparatively high level.

Our organism as well as its subsystems (including their psychic elements) can be trained in some way or other all our life, even in old age. Therefore sporting activities as a means of preventing premature ageing will be the more effective the more parts of our organic systems and dispositions are trained.

Such a conception of sport for the elderly must not isolate the problem of physical fitness from other problems of old age. Nor should it be confined to improving endurance only, or to promoting other rather limited aspects of physical fitness. 


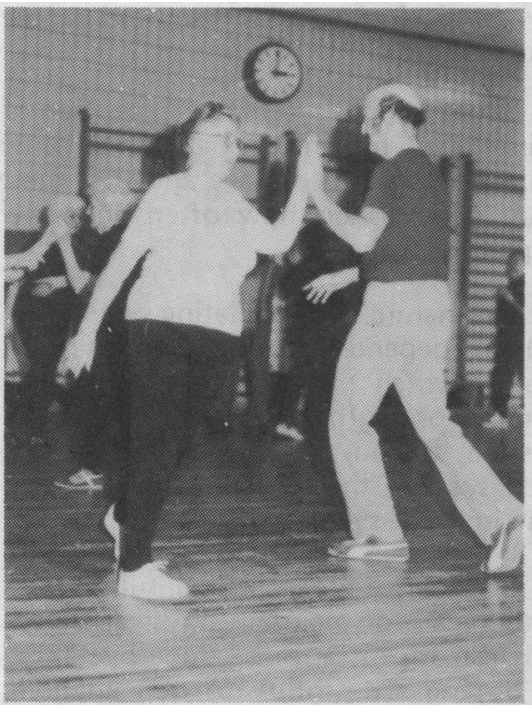

Fig. 1: Warming up by dancing. Persons aged 59 and 65.

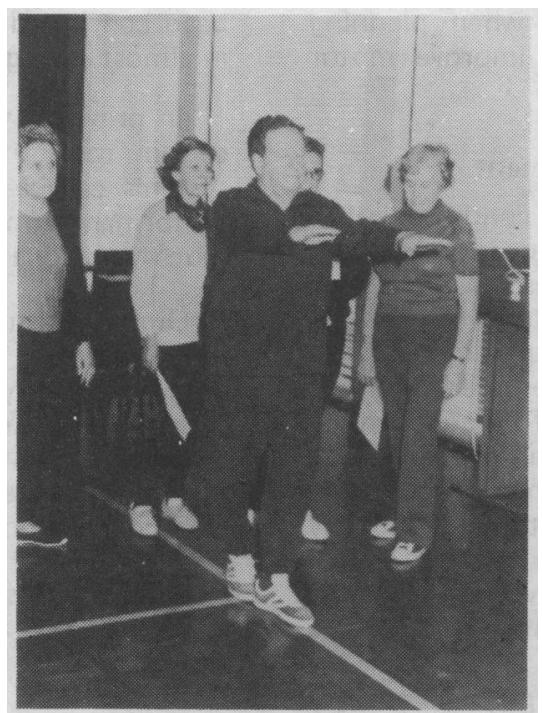

Fig. 2: Testing dynamic equilibrium. 71 year-old person.

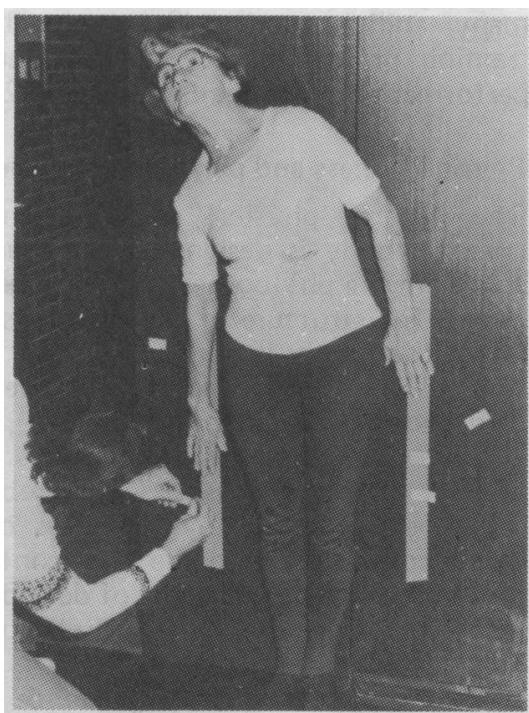

Fig. 3: Testing flexibility of the vertebrae. 69 year-old person.

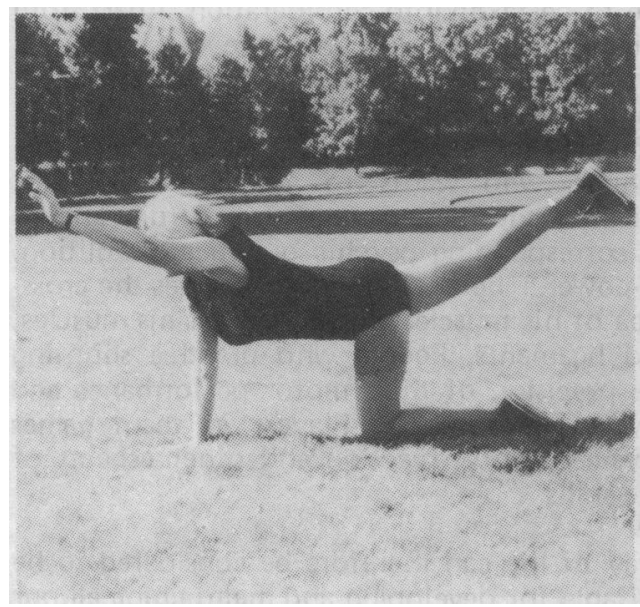

Fig. 4: Strengthening the muscles of the backside. Excellent performance by a 69 year-old person.

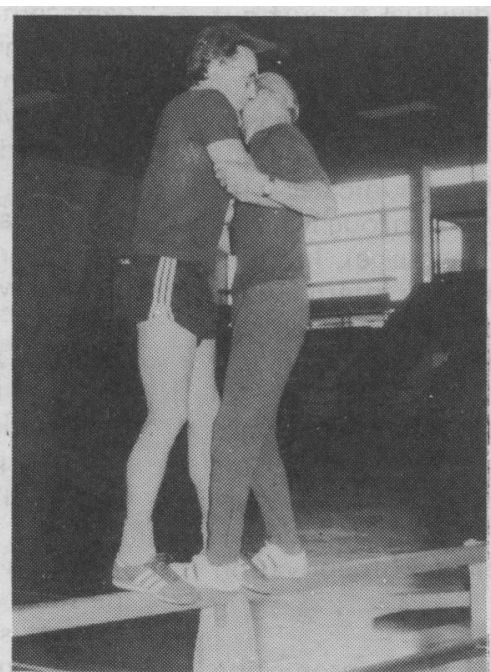

Fig. 5: $a+b$ Training dynamic balance by passing one another on a small bench - for able persons only. 69 year-old person and PT-instructor.

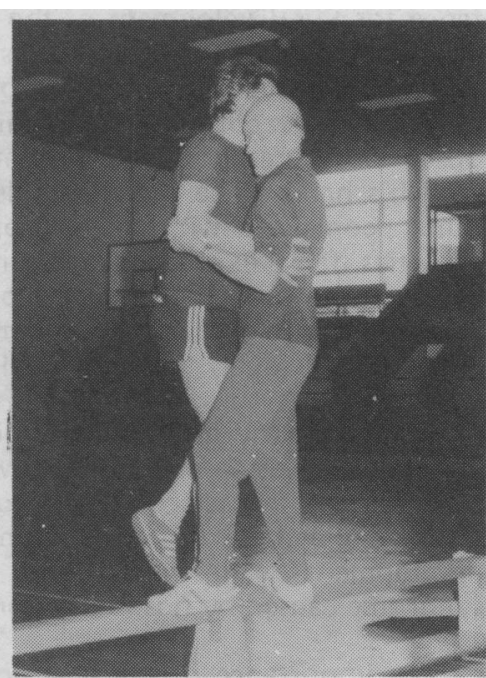




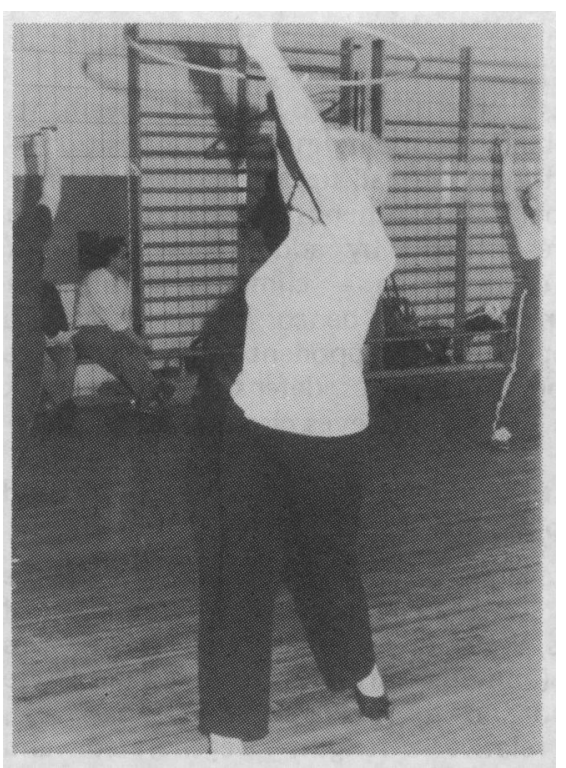

Fig. 6: Developing flexibility of the vertebrae. 64 year-old person.

These factors of motor mobility and physical fitness can be related to certain subsystems of our organism which serve as a physical basis (Table I).

\section{TABLE I}

Subsystems of motor mobility and their physical basis.

\begin{tabular}{|c|c|c|}
\hline Physical basis & Ability & \multirow{8}{*}{$\begin{array}{l}\text { Including mental } \\
\text { abilities such as } \\
\text { perception, recog- } \\
\text { nition, thinking } \\
\text { and qualities con- } \\
\text { cerning the will- } \\
\text { power }\end{array}$} \\
\hline $\begin{array}{l}\text { Central nervous } \\
\text { system }\end{array}$ & Co-ordination & \\
\hline \multirow[t]{2}{*}{$\begin{array}{l}\text { Musculo-skeletal } \\
\text { system }\end{array}$} & $\begin{array}{l}\text { Ability to relax the } \\
\text { muscular system }\end{array}$ & \\
\hline & $\begin{array}{l}\text { flexibility } \\
\text { strength }\end{array}$ & \\
\hline $\begin{array}{l}\text { Cardio-vascular and } \\
\text { respiratory systems }\end{array}$ & Endurance & \\
\hline $\begin{array}{l}\text { Autonomic } \\
\text { nervous system }\end{array}$ & $\begin{array}{l}\text { Stress tolerance (veg. } \\
\text { adaptation) }\end{array}$ & \\
\hline Metabolism & $\begin{array}{l}\text { Regulation of the } \\
\text { body-weight }\end{array}$ & \\
\hline Immune system & $\begin{array}{l}\text { Resistance against } \\
\text { infection }\end{array}$ & \\
\hline
\end{tabular}

Each of these subsystems can impair mobility and physical fitness considerably, if it fails to work adequately. In practice each of these factors should therefore be sufficiently considered. Good results can only be obtained by a so-called "complex" training which consists of as many different sports and exercises as possible.

\section{Co-ordinative skills (central nervous system)}

Co-ordination means the well-ordered co-operation of

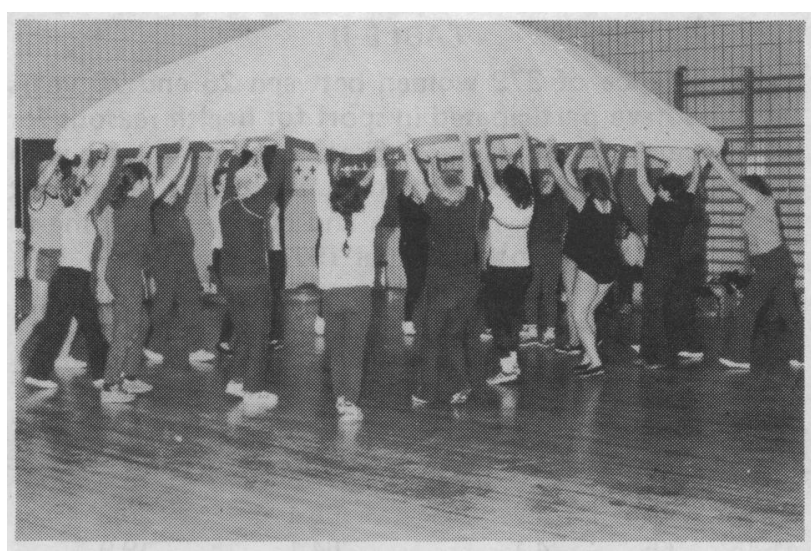

Fig. 7: Playing with the parachute. Mixed group of seniors and students.

the central nervous system and the skeletal muscles. Co-ordination appears in different forms, for instance

- in agility as the ability to react quickly with controlled and nimble movements;

- in the ability to balance, to keep some object in equilibrium or (to keep in equilibrium) the body when standing or moving on a small area of support. Balance is a basic requirement of human posture and movement. Standing, walking, running or climbing stairs are not possible without unimpaired balance.

Protasova et al (1974) examined more closely how the ability to balance develops in the course of ageing (Table II). Belorusova (1965, 280) furnished proof that the ability to balance can be trained well even in old age (Table III).

- A third form of co-ordinative skills is the ability to determine one's position in relation to one's surroundings, i.e. the ability to determine and change the position and movement of the body in relation to place and time without losing orientation.

These aspects of co-ordinative performance, as well as some others are vital for the elderly. Lack of coordinative skills, e.g. inadequate agility or unsatisfactory balance, reduces a person's competence in moving, increases the risk of accident, adversely affects selfconfidence and confines a person's freedom of movement and living-space. That is why it is most important that every fitness programme contains exercises to improve agility (e.g. elements of games), static and dynamic balance, balance of objects and the ability to determine one's position.

The great importance of co-ordinative skills in sports 
TABLE II

Static balance of 379 women between 26 and 70 years old who have participated in sport for health reasons for 1 to 5 years. Means of 4 exercises: standing upright with eyes open and closed, standing with the head bent backwards with the eyes open and closed (according to Protasova et al 1974).

\begin{tabular}{lllll} 
Age & $\mathrm{n}$ & $\begin{array}{l}\text { Average } \\
\text { amplitude of } \\
\text { swayings } \\
\text { (mm) }\end{array}$ & $\begin{array}{l}\text { Amount of } \\
\text { swayings } \\
\text { per minute }\end{array}$ & $\begin{array}{l}\text { Maximum } \\
\text { amplitude } \\
\text { of swayings } \\
(\mathrm{mm})\end{array}$ \\
\hline $26-30$ & 23 & 3.9 & 65.8 & 20.3 \\
$31-35$ & 41 & 4.0 & 62.5 & 18.5 \\
$36-40$ & 49 & 4.2 & 65.4 & 20.2 \\
$41-45$ & 56 & 4.1 & 64.1 & 19.9 \\
$46-50$ & 34 & 4.4 & 69.0 & 20.7 \\
$51-55$ & 51 & 4.5 & 67.6 & 24.9 \\
$56-60$ & 61 & 5.0 & 66.9 & 28.9 \\
$61-65$ & 37 & 5.1 & 69.4 & 31.6 \\
$66-70$ & 27 & 5.2 & 80.0 & 27.3
\end{tabular}

TABLE III

Improvement in the static balance of $\mathbf{4 0}$ subjects $\mathbf{5 0 - 7 3}$ years old, after 9 months training, standing on a line (Belorusova 1965, 280).

\begin{tabular}{lllll} 
Age & $\mathrm{n}$ & $\begin{array}{l}\text { 1. Test } \\
\text { (before training) }\end{array}$ & $\begin{array}{l}\text { 2. Test } \\
\text { (after training) }\end{array}$ & Difference \\
\hline $50-59$ & 20 & $11.0 \mathrm{~s}$ & $22.6 \mathrm{~s}$ & +11.6 \\
$60-73$ & 20 & $3.5 \mathrm{~s}$ & $10.8 \mathrm{~s}$ & +7.3
\end{tabular}

for the elderly becomes obvious when learning movements. A high degree of agility facilitates learning movements, e.g. acquiring new skills, learning new exercises and sports. It also enables a person to use his abilities economically and to relieve various organic systems. When learning new movements an older person should first practise slowly and he should take his time. Working under pressure interferes with the learning process in old age. To give variety to the learning process one should make good use of the wide choice of gymnastics and rhythmic exercises with and without small apparatus, with and without a partner, and of simple forms of active games.

To develop agility systematically the following methods can be recommended:

- Change the performance of the movements: slower/ faster, wider/narrower (both in various degrees), in different rhythms.

- Counter-movements: from the right side to the left instead of moving from the left side to the right; use the left hand instead of the right, etc.

- Change practising conditions: unusual starting positions (half turn before executing a shot); make practising conditions more difficult (smaller area of support, throw a ball that is smaller or heavier).

- Make the task more difficult by adding movements or new problems (skipping in standing position in motion; throw the ball up and catch it again throw the ball up, clap hands and catch it); make things more difficult by adding new problems (balancing on a bench - climbing an obstacle while balancing on a bench; dribble round a passive opponent - opponent fakes defensive action - opponent takes defensive action; walk along a line - walk with eyes closed).

The ability of the muscles to relax, flexibility and strength (musculo-skeletal system)

In the course of ageing the elasticity and stability of the muscles, tendons and ligaments deteriorate, the tonus of the muscles drops, the cross-sectional area of the muscles becomes smaller (muscular atrophy) and the mass of the muscles in proportion to body-weight becomes less, thus reducing relative strength. Degenerated and damaged joints impair flexibility.

Such processes may reduce the mobility of older people considerably. Muscular atrophy increases the danger of orthopaedic disabilities and it diminishes body control. Less body control increases the risk of accident, so every fitness programme should also contain exercises to strengthen the muscles to work against atrophy in old age. One must not begin to strengthen muscles, however, before they have thoroughly been warmed up, limbered up and stretched sufficiently. You should warm up yourself by slowly moving large groups of muscles and not by stretching muscles as is done in many aerobic programmes.

All large groups of muscles should be strengthened, of the trunk as well as those of the extremities. Though the results of static strength training and those of dynamic strength training are said to be similar, in sports for the elderly we should prefer dynamic strength training. In static strength training holding the breath very tightly may cause considerable dangers because it is associated with great fluctuations in blood pressure. That is why in dynamic strength training, too, working out fast against high resistance should be avoided by performing exercises that offer only a little and later on moderate resistance. Those should be repeated frequently. Push-ups and pull-ups should therefore be avoided by older people who practise only occasionally. Train muscles gradually over a comparatively long time, because after finishing training, strength that has taken a long time to develop can be kept up longer than strength that has been gained very fast.

Flexibility denotes the range of each joint. It depends on the anatomy of the joint and on how much the muscles can be stretched. Flexibility makes it easier to 
solve many everyday problems, from getting dressed to cleaning the house, and it is a most important factor of safety. Flexibility helps to prevent accidents. Many sports such as swimming and volleyball, require sufficient flexibility.

To improve flexibility the muscles must first be warmed up thoroughly; you also must improve the ability of the muscles to relax. Older persons should be satisfied with exercises that stretch the muscles actively, exercises in which the muscles are stretched by the action of their antagonists. Passive stretching exercises performed with the help of partners or weights should be avoided. Jerky and fast stretching exercises can damage muscles, tendons, ligaments and joint capsules.

\section{Endurance (cardiovascular system)}

The importance of endurance training as a preventive measure against diseases of the cardiovascular system is undisputed. A person who has exercised regularly all his life can still practise endurance sports even if there is a certain deterioration in the functions of the musculoskeletal system. He knows by experience how much and in which way he should strain himself. Old people, however, who have only little or no experience at all can - as a rule - hardly be motivated to take up longdistance running or jogging. They are not willing to bear the necessary strain. Often endurance training is made more difficult or even impossible because of overweight and orthopaedic disabilities.

Many people suffering from such infirmities may still be capable of swimming. Endurance training in swimming can only be performed effectively, if special attention is paid to a proper swimming technique, which enables a person to swim smoothly and without interruption over longer distances. Stiff swimming movements may lead to undue strain on the cardiovascular system. Nor should we underestimate the dangers of hypothermia and the incidence of orthopaedic complaints in the hip-joints, knee-joints and in the cervical area of the spine. Endurance could be improved best by alternating regularly between different endurance sports, especially running, swimming, cycling, and long-distance skiing. When cycling, an untrained person should avoid going uphill over longer distances. This would require strenuous efforts and could result in cramp in arms and shoulders, in holding the breath very tightly and great fluctuations in blood pressure.

The ideal endurance sport, however, is long-distance skiing, because in this sport arms and shoulders, too, are employed in an alternating thythm when moving along. Even older people can still learn long-distance skiing, if they first get through an appropriate programme of conditioning exercise to improve strength and co-ordinative skills, and many are highly qualified for longdistance skiing (Table IV).

\section{TABLE IV}

The average running times and best times in 1972 at Wasa-Race and at Engadine Skiing-Marathon (Schneiter 1973, 59 seq.).

\begin{tabular}{lrcll} 
& \multicolumn{2}{l}{ Average running time } & Best time & \\
Age & $86 \mathrm{~km}$ & $42 \mathrm{~km}$ & $86 \mathrm{~km}$ & $42 \mathrm{~km}$ \\
\hline 21 & $9: 16: 37$ & $3: 43: 58$ & $6: 39: 18$ & $2: 16: 25$ \\
30 & $8: 49: 33$ & $3: 42: 42$ & $5: 55: 56$ & $2: 16: 39$ \\
40 & $8: 52: 07$ & $4: 00: 13$ & $5: 55: 09$ & $2: 26: 03$ \\
50 & $9: 29: 57$ & $4: 17: 58$ & $6: 37: 44$ & $2: 25: 52$ \\
60 & $10: 11: 24$ & $4: 32: 39$ & $8: 02: 10$ & $2: 49: 18$
\end{tabular}

In endurance training the endurance method is to be preferred over the interval method. The training load should be guided by a person's maximal pulse rate minus his age. As a guide-line of how fast to run, running without getting out of breath should be accepted. Before starting a running programme an untrained person must undertake a light programme of conditioning exercise for several months to strengthen the musculo-skeletal system (Osipov, 1961).

\section{Vegetative adaptability/stress tolerance (autonomic nervous system)}

In the course of ageing the autonomic nervous system shows marked deterioration in its ability to adapt to changes in strain. In old age this often results in insomnia, vertigo, constipation, and other complaints. Well-balanced physical training can improve the ability of the autonomic nervous system to adapt to changing strain, thus increasing stress tolerance. After physical exercise the parasympathetic nervous system becomes more active than that of an untrained person. This results in a state of relaxation and well-being, so physical exercise is helpful in accelerating recovery from stress. In this context recreative sports and remedial exercises can serve our purpose best, provided that they contain elements of play and that people enjoy them. They should also offer a great variety of activities. Such activities should not exceed moderate to average strain. Among those there are moderate exercises from endurance sports, which have to be done for some time, as well as simple yet diversified forms of gymnastics. On the other hand, we should realise that undue strain through sport is a form of stress in itself, and may result in the same kind of stress symptoms as does occupational stress; namely troubled sleep, over-excitement, and irritability.

\section{Controlling body-weight (metabolism)}

Being overweight considerably reduces physical fitness and mobility. However, the influence of sporting activities on the process of controlling body-weight is overestimated. A high percentage of metabolism takes 
place in the muscles. The muscular system declines noticeably in old age, which often leads to overweight, unless lowering calorie intake or consuming calories through physical exercise. When taking physical exercise the consumption of energy is relatively small (Table V). According to Halhuber (1971) an average longdistance skiing runner consumes only 594 cal. per hour at a speed of $6 \mathrm{~km} / \mathrm{hr}$. and $648 \mathrm{cal}$. at a speed of 7.5 $\mathrm{km} / \mathrm{hr}$. In order to consume $750 \mathrm{cal}$. a long-distance ski runner has to run for one hour at a speed of 12 $\mathrm{km} / \mathrm{hr}$. We can proceed on the assumption that a 60 year-old person only needs $4 / 5$ of the food he needed at the age of 20 . Thus in old age a lasting reduction of overweight through physical exercise can only be achieved by simultaneously lowering food intake.

\section{Resistance to infections (immune system)}

The influence of sport for older people on the immune system has hardly been studied yet. Outdoor sport seems to have a positive influence on reducing proneness to infection, thus helping to reduce the risk of disease (Dancenko, 1965; Eitner et al, 1966). Liesen (1977) found out that the immune system of untrained persons in their sixties and seventies can be activated by endurance training.

It can be concluded from this that fitness training should be performed outdoors as often as possible even in winter, provided that those taking part are used to physical activities in cold weather. The following outdoor sports can be recommended for older people: running, long-distance skiing, skiing-tours, cycling.

\section{Speed}

In this context the problem of speed will not be discussed in detail. Speed in cyclic movements (such as sprints) puts too much strain on the musculo-skeletal system. The sprinter must perform anaerobic work, which cannot be recommended for older people. Empiric studies on the ageing process of the sprinting speed of older persons have only been made in the Soviet Union (Table VI). There is, however, in such tests a great risk of injuries. Speed in acyclic movements, however, is encouraged because the ability to move fast against some resistance is a most important factor in the prevention of accidents and the exercises necessary for this purpose can easily be included in the training programme.

\section{SUMMARY}

A systematic improvement of physical performance can hardly be achieved if the main aim is maintaining and developing just one motor ability (such as strength or endurance) or if training is confined to only one single sport and to only one or two groups of exercises (such as running and gymnastics). One can only maintain and improve physical performance systematically,

\section{TABLE V}

Energetic expenditure during long-distance-skiing (according to Halhuber 1971).

\begin{tabular}{|c|c|c|c|c|}
\hline \multirow[t]{2}{*}{ Speed } & \multicolumn{2}{|c|}{$\begin{array}{l}\mathrm{O}_{2-} \\
\text { consump- Power } \\
\text { tion (Watt/ } \\
(\mathrm{ml} / \mathrm{min}) \mathrm{min})\end{array}$} & \multicolumn{2}{|c|}{$\begin{array}{l}\text { Calorie-consump- } \\
\text { tion } \\
\text { per min per hour }\end{array}$} \\
\hline & \multicolumn{4}{|c|}{ It can be estimated for trained skiers } \\
\hline $120 \mathrm{~m} / \mathrm{min}=7.2 \mathrm{~km} / \mathrm{h}$ & 1600 & 100 & 8.0 & 480 \\
\hline $150 \mathrm{~m} / \mathrm{min}=9.0 \mathrm{~km} / \mathrm{h}$ & 1900 & 125 & 9.5 & 570 \\
\hline \multirow[t]{2}{*}{$200 \mathrm{~m} / \mathrm{min}=12.0 \mathrm{~km} / \mathrm{h}$} & 2450 & 175 & 12.5 & 750 \\
\hline & \multicolumn{4}{|c|}{$\begin{array}{l}\text { It can be estimated for the "average } \\
\text { skier" }\end{array}$} \\
\hline $100 \mathrm{~m} / \mathrm{min}=6.0 \mathrm{~km} / \mathrm{h}$ & 1980 & 130 & 9.9 & 594 \\
\hline $125 \mathrm{~m} / \mathrm{min}=7.5 \mathrm{~km} / \mathrm{h}$ & 2160 & 150 & 10.8 & 648 \\
\hline
\end{tabular}

\section{TABLE VI}

Performance in $\mathbf{3 0} \mathrm{m}$-race of $\mathbf{3 0 - 7 0}$ years old women depending on age and beginning of training (Osipov/ Protasova 1978, 46). The figures of the untrained are in brackets according to Rubcov (1974, 54 seq.).

\begin{tabular}{|c|c|c|c|}
\hline $\begin{array}{l}\text { Age and beginning } \\
\text { of training }\end{array}$ & \multicolumn{3}{|c|}{$\begin{array}{l}\text { 30-metre race flying start } \\
\qquad \mathrm{n} / \text { mean }\end{array}$} \\
\hline $\begin{array}{l}30 \text { up to } 39 \text { years } \\
\text { average group } \\
\text { performance }\end{array}$ & & 88 & 5.42 \\
\hline up to 1 year & & 28 & 5.60 \\
\hline 1.5 years & & 41 & 5.24 \\
\hline $6-10$ years & & 19 & 5.43 \\
\hline $\begin{array}{l}40 \text { up to } 49 \text { years } \\
\text { average group } \\
\text { performance }\end{array}$ & (untrained $20-24$ yr.: & $\begin{array}{r}41 \\
111\end{array}$ & $\begin{array}{l}5.531 \\
5.52\end{array}$ \\
\hline up to 1 year & & 24 & 6.24 \\
\hline 1.5 years & & 57 & 5.77 \\
\hline $11-18$ years & & 30 & 5.56 \\
\hline $\begin{array}{l}50 \text { up to } 59 \text { years } \\
\text { average group } \\
\text { performance }\end{array}$ & (untrained $30-34$ yr.: & $\begin{array}{r}52 \\
152\end{array}$ & $\begin{array}{l}6.241 \\
6.48\end{array}$ \\
\hline up to 1 year & & 14 & 6.71 \\
\hline $1-5$ years & & 56 & 6.54 \\
\hline $11-18$ years & & 82 & 6.20 \\
\hline $\begin{array}{l}60 \text { up to } 64 \text { years } \\
\text { average group } \\
\text { performance }\end{array}$ & (untrained $40-44$ yr.: & $\begin{array}{r}133 \\
88\end{array}$ & $\begin{array}{l}7.21 \\
6.67\end{array}$ \\
\hline 1.5 years & & 44 & 6.76 \\
\hline 11.18 years & & 44 & 6.58 \\
\hline $\begin{array}{l}65 \text { up to } 69 \text { years } \\
\text { average group } \\
\text { performance }\end{array}$ & luntrained $45-49$ yr.: & $\begin{array}{l}67 \\
76\end{array}$ & $\begin{array}{l}7.21 \\
7.28\end{array}$ \\
\hline 1.5 years & & 13 & 7.34 \\
\hline 11.18 years & & 63 & 7.23 \\
\hline $\begin{array}{l}70 \text { years and older } \\
11-18 \text { years }\end{array}$ & & 45 & 7.93 \\
\hline
\end{tabular}


if the training plans include as wide a range of abilities and skills and as great a variety of activities as possible. Physical training must be supplemented with further steps in health care, such as a suitable diet and limiting the so-called "risk-factors" such as smoking.

The main reason why physical training should be included in geroprophylaxis is to maintain elderly people's mobility and well-being. Thus they have a better chance of becoming independent, self-sufficient and satisfied with life.

\section{ZUSAMMENFASSUNG}

Für die Erhaltung und Entwicklung der Mobilität im Alter ist motorische Aktivität unerläßlich. Aus der Phylogenese und Ontogenese des Menschen wird die Bedeutung der Bewegung für die Entwicklung der Persönlichkeit und für die Erhaltung der Leistungsfähigkeit im Alter aufgewiesen. Viele Phänomene, die man bisher als unabwendbare Folgen des Alternsprozesses betrachtet hat, erklären sich als Folgen mangelnden Trainings. Dieser Gedanke wird an den wichtigsten Teilsystemen unseres Organismus (wie Zentrales Nervensystem, Herz-Kreislauf-Gefäß-System u.a.) näher erläutert. Um diese Teilsysteme und damit den Gesamtorganismus optimal funktionsfähig zu erhalten, ist deren spezifische Anpassungsfähigkeit durch sportliches Training zu verbessern. Alterssport und Seniorengymnastik sollten also gleichermaßen Koordination, Entspannungsfähigkeit der Muskulatur, Gelenkigkeit, Kraft, Ausdauer, Streßtoleranz, Kontrolle des Körpergewichts und Resistenz gegen Infektionen verbessern.

Je breiter auf diesem Wege Alterssport und Seniorengymnastik angelegt sind, um so eher werden sie als Prophylaxe gegen vorzeitiges Altern wirksam sein, die motorische Mobilität als Grundlage eigenständiger Lebensführung erhalten und über die Vermittlung neuer Erfahrungen und Erlebnisse das Wohlbefinden und die Lebensqualität im dritten Lebensalter erhöhen.

\section{REFERENCES}

Belorusova, A. V., 1965. Izmenenie gibkosti, ravnovesija i bystroty dvizenij u lic srednego i pozilogo vozrasta v svjazi s zanjatijami gimnastikoj. In: (Körperkultur - Quelle der Langlebigkeit). Red.: Cebotarev, D. F., Korobkov, A. V., Marcuk, P. D. u.a. Moskau: Fizkul'tura i Sport 278-281, 3 Tab.

Dancenko, I. P., 1965. Opyt kruglogodicnych zanjatij na otkrytom vozduche s licami srednego i pozilogo vozrasta. In: (Körperkultur - Quelle der Langlebigkeit). Red.: Cebotarev, D. F., Korobkov, A. V., Marcuk, P. D. u.a. Moskau: Fizkul'tura i Sport 262-272, 3 Tab.

Eitner, Siegfried, Schuchardt, Ch. and Tröger, A., 1966. Die Bedeutung des Ausgleichstrainings für die Gesundheit des älteren Menschen. In: Sport und Körperkultur des älteren Menschen. Bericht der Jahrestagung 1964 der Deutschen Gesellschaft für Sportmedizin in der DDR, Rostock-Warnemünde, 16.-20.9. 1964 Hrsg.: Ries, Werner. Leipzig: Barth 122-141, 10 Tab., 21 Lit.

Halhuber, M. J., 1971. Zur Frage der körperlichen Belastbarkeit alternder und alter Menschen. In: mda - Med.d. alternden Menschen, Erlangen 1 1, 33-36, 4 Tab., 16 Lit.

Hollmann, W., Liesen, H., Rost, R. and Kawanats, K., 1978. Über das Leistungsverhalten und die Trainierbarkeit im Alter. In: Z.Gerontol., Darmstadt 11 6, 312-324.

Jablonovskij, I. M., 1965. Issledovanija nekotorych dvizenij u lic srednego i pozilogo vozrasta. In: Fiziceskaja kul'tura istocnik dolgoletija. Red.: Cebotarev, D. F., Korobkov, A. V., Marcuk, P. D. u.a. Moskau: Fizkul'tura i Sport 281-286, 3 Tab., 2 Lit.

Jokl, Ernst, 1970. Alter und Leistung. In: Alter und Physiotherapie. 2. Bad Sodener Geriatrisches Gespräch, 8. Mai 1970 Hrsg.: Böhlau, Vokmar. Stuttgart, New York: Schattauer 31-44, 2 Abb., 2 Lit.

Lehr, Ursula, 1974. Psychologie des Alterns. 2. Aufl. Heidelberg: Quelle \& Meyer 348 P., 18 Darst., = UTB. Bd. 55.

Lehr, Ursula, 1978. Körperliche und geistige Aktivität - eine Voraussetzung für ein erfolgreiches Altern. In: Z.Gerontol. Darmstadt 11 290-299.

Lehr, Ursula, 1981. Turnen und Sport im Alter. In: Akt.Gerontol., Stuttgart, New York, 11 3, 100-105. 
Liesen, Heinrich, 1977. Metabolische Adaptationen an akute und chronische Ausdauerbelastungen. Köln: Deutsche Sporthochschule, Habil.-Schrift 191 P., 54 Darst., 40 Tab., 446 Lit.

Meusel, Heinz, 1982. Sport, Spiel, Gymnastik in der zweiten Lebenshälfte. Ziele, Training, Unterricht, Organisation. Bad Homburg: Limpert 335 P., 14 Abb., 55 Tab., 460 Lit.

Osipov, I. T., 1961. Organizacija, zadaci i planirovanie zanatij (Organisation, Aufgaben und Planung des Übungsbetriebs). In: (Körperkultur für ältere Menschen. Lehrbuch für des Gruppentraining). Red.: Osipov, I. T. Hrsg.: Zentralrat der Sportvereinigungen und -organisationen der UdSSR. Moskau: FiS 13-27, 7 Tab.

Osipov, I. T. and Protasova, M. V., 1978. Vlijanie mnogoletnich zanjatij fiziceskoj kul'turoj na nekotorye pokazateli dvigatel'noj funkcii ljudej srednego i starsego vozrasta. In: Teor.Prakt.fiz.Kul't., Moskau 31, 2, P. 45-48, 2 Darst., 2 Tab., 11 Lit.

Protasova, M. V., Bondarevskij, E. Ja, Levando, V. A. et al, 1974. O vozrastnych izmenenijach ustojcivosti stojanija zenscin 26-70 let. In: Teor.Prakt.fiz.Kul't.Moskau 37 9, 44-46, 2 Tab., 4 Lit.

Rubcov, A. T., 1974. Fiziceskaja podgotovlennost' zenscin 20-49 let, rance ne zanimavsichsja fiziceskoj kul'turoj. In: Teor.Prakt.fiz.Kul't., Moskau 37 6, 53-55, 2 Tab.

Schneiter, Ch., 1973. Ausdauerleistung und Alter. In: Jugend u.Sport, Magglingen. 30 2, 57-61, 4 Darst., 4 Tab.

Singer, Roland (Hrsg.), 1981. Alterssport. Versuch einer Bestandsaufnahme. Schorndorf: Hofmann 212 P., Abb., Tab., Lit.

Smith, E. L. and Reddan, W., 1976 "Physical activity - a modality for bone accretion in the aged". In: Amer.J. Roentgenol., Springfield, III. 126 6, 1297, 1 Darst., 5 Lit.

\section{THE LONDON HOSPITAL MEDICAL COLLEGE (University of London)}

\section{DIPLOMA IN SPORTS MEDICINE}

Applications are invited from medical practitioners seeking training in this field, and who wish to attend a course leading to a College Diploma in Sports Medicine. The number accepted for this course will be limited.

This is a Primary Care Course, designed for the doctor who is closely involved with sport, either as a General Practitioner, as a Medical Officer attached to sporting facilities, or as Team Doctor. It is a very extensive course, with over $\mathbf{5 0 0}$ hours of timetabled teaching. Anatomical, physiological, pharmacological and psychological aspects of the subject will be covered by a course team including many guest speakers of international repute. Laboratory work at The London will be supplemented by visits to several laboratories specialising in fitness testing for athletes, or other aspects of exercise physiology. Clinical training in the prevention, recognition, primary care and rehabilitation of sports injuries will include visits to Sports Clinics, Rehabilitation Centres, and Specialist Physiotherapy Clinics. The course will not provide a training in the application of orthopaedic surgery for sports injuries.

The course begins annually in early October, and consists of one academic year of three eight-week terms.

Further information and application forms are available from Miss P. Thompson, Secretary, The Diploma Course in Sports Medicine, Surgical Unit, The London Hospital, Whitechapel E1 1BB. Telephone 01-247-5454 ext. 632. 